\title{
Diurnal Effects on Chinese Wild Ledum palustre L. Essential Oil Yields and Composition
}

\author{
Liangliang Zhang, Hongxiao Wang, Yongmei Wang, Man Xu, Xinyu Hu \\ Institute of Chemical Industry of Forest Products, CAF, Nanjing, China \\ Email: zh1120086@163.com
}

How to cite this paper: Zhang, L.L. Wang, H.X., Wang, Y.M., Xu, M. and Hu, X.Y. (2017) Diurnal Effects on Chinese Wild Ledum palustre L. Essential Oil Yields and Composition. Journal of Analytical Sciences, Methods and Instrumentation, 7, 4755.

https://doi.org/10.4236/jasmi.2017.72005

Received: April 21, 2017

Accepted: June 10, 2017

Published: June 13, 2017

Copyright $\odot 2017$ by authors and Scientific Research Publishing Inc. This work is licensed under the Creative Commons Attribution International License (CC BY 4.0).

http://creativecommons.org/licenses/by/4.0/

\begin{abstract}
This study was conducted to evaluate the diurnal effect on essential oil yield and composition of Ledum palustre L. grown in northern Inner Mongolia, China. Essential oil content and composition were determined and compared as a function of different harvesting times viz. 7:00 AM, 11:00 AM, 3:00 PM, 7:00 PM, and 11:00 PM within a day. The essential oil obtained by hydrodistillation was investigated by gas chromatography-mass spectrometry (GCMS). The yield of essential oil was varied from $1.21 \%$ to $1.62 \%$; the maximum oil yield was obtained at 3:00 PM and the minimum at 7:00 PM. Similar to oil yield, qualitative difference in essential oil composition of $L$. palustre was observed. For the best essential oil yields, L. palustre should be harvested during 11:00 AM to 3:00 PM.
\end{abstract}

\section{Keywords}

Ledum palustre L., Diurnal Changes, Essential Oil Yield, Essential Oil Composition, Alpha-Thujenal

\section{Introduction}

Leum palustre L., also known as wild rosemary or marsh tea, is an evergreen low shrub growing wild in northern China and America, northern and central Europe. The plant grows in peaty soils, shrubby areas, moss and lichen tundra. Its leaves and flowers have a strong smell causing a headache in some people. All parts of the plant contain poisonous terpenes that affect the central nervous system, causing aggressive behaviour. L. palustre is widely used in folk medicine and homoeopathy for the treatment of rheumatism, arthrosis, and insect bites [1]. The expectorant and antitussive effect of the marsh tea is due to the ledol contained in the plant's essential oil [1]. The composition of the essential oil from L. palustre varies considerably with habitat [2] [3]. The major components 
present in the essential oil of L. palustre are (+)-ledol [4], (-)-palustrol [4] [5], (-)-cyclocolorenone [4], myrcene, p-cymene and limonene [4] [6]. Essential oils were obtained from different parts of $L$. palustre (all overground parts, shoots and leaves) plants. The content of oils in young leaves and shoot was higher than in the corresponding aged parts [4]. Ledol was determined in the leaf essential oil and three compounds (ledol, palustrol and germacron) in shoot oil [4]. The composition of the essential oil varied in a wide range in different localities. In recent years, the well-known repellent properties of the essential oil of wild $L$. palustre against bedbugs, clothing moths and other insects are valued [7] [8]. The L. palustre has been the focus of many scientific researches investigating its shoots and the essential oil for different bioactivities [9]. The promising antimicrobial, antioxidant and antidiabetic properties were reported [1].

Although the biosynthesis of secondary metabolites is controlled by genetic processes, it is also strongly affected by climatic conditions such as light, temperature, irrigation, soil and nutrition as well as the season and the time plant material is harvested [10]-[15]. Previous studies found significant impact of diurnal changes on essential oil yield and composition on a number of crops such as basil (Ocimum gratissimum L.) [16], Pelargonium sp. [17], oil-bearing rose (Rosa damascene Mill.) [18], dill Cistaceae (Cistus monspeliensis) [19], lavender (Lavandula angustifolia Mill.) [20], Eucalyptus spp. [21], and spearmint (Menthaspicata L.) [10]. However, diurnal changes in Chinese wild L. palustre L. essential oil yield and composition are not known. The objective of this study was to evaluate the effect of diurnal variation on yield and composition, of the essential oil from the aerial parts of L. palustre L. grown wild in northeastern China.

\section{Experimental Procedures}

\subsection{Materials}

The aerial parts of $L$. palustre were collected in Northern Inner Mongolia, China, in August 2016. All samples were obtained within a $24 \mathrm{~h}$ period. L. palustre was at flowering stage at the time of harvest, to ensure the best essential oil content and composition. The plant was harvested every 4 h: 7:00 AM, 11:00 AM, 3:00 $\mathrm{PM}$, 7:00 PM, and 11:00 PM, each harvest in three replicates, resulting in 15 plant samples. Each pant sample was around $2 \mathrm{~kg}$ of fresh weight. The fresh $L$. palustre samples were dried in a well-ventilated barn at shade. Voucher specimens (No. CAF20160001) were deposited at the Institute of Chemical Industry of Forest Products, Chinese Academy of Forestry.

\subsection{Extraction of Essential Oil}

The ground powders of all $15 \mathrm{~L}$. palustre samples (each around $1.5 \mathrm{~kg}$ ) were subjected to hydrodistillation using a modified Clevenger-type apparatus (Senco, SENCO Technology Co., Ltd.) for $5 \mathrm{~h}$. The beginning of each distillation was measured when the first drop of essential oil was out of the condenser and in the separator. At the end of the each distillation, the power was turned off; the oil and the water were decanted from the separator into glass vials. The oil was se- 
parated from the water and anhydrous sodium sulphate was used to remove water after extraction. The essential oil was stored in an airtight container in a refrigerator at $4^{\circ} \mathrm{C}$. The essential oil content (yield) was calculated as grams of oil per $100 \mathrm{~g}$ of dry herbage.

\subsection{Analysis of Essential 0il}

The samples were analysed on a Varian Saturn 2000 System using a 1079 injector that had been fitted with the Chromato Probe kit. This kit allows the thermal desorption of small amounts of solids or liquids contained in quartz microvials, or in our case the thermal desorption of the trapped volatiles. The adsorbent tube was loaded into the probe, which was then inserted into the modified GC injector. The injector split vent was opened (1/20) and the injector heated to $40^{\circ} \mathrm{C}$ to flush any air from the system. The split vent was closed after 2 minutes and the injector was heated at $200^{\circ} \mathrm{C} /$ minute, and then held at $200^{\circ} \mathrm{C}$ for 4.2 minutes, after which the split vent opened (1/10) and the injector cooled down.

A ZB-5 column (5\% phenyl polysiloxane) was used for the analyses $(60 \mathrm{~m}$ long, inner diameter $0.25 \mathrm{~mm}$, film thickness $0.25 \mu \mathrm{m}$, Phenomenex). Electronic flow control (EFC) was used to maintain a constant heliumcarrier gas flow of 1.8 $\mathrm{mL} / \mathrm{minute}$. The GC oven temperature was held for 7 minutes at $40^{\circ} \mathrm{C}$, then increased by $6^{\circ} \mathrm{C}$ per minute to $250^{\circ} \mathrm{C}$ and held for 1 minute. The MS interface was $260^{\circ} \mathrm{C}$ and the ion trap worked at $175^{\circ} \mathrm{C}$. Themass spectra were taken at $70 \mathrm{eV}$ (in EI mode) with as canning speed of $1 \mathrm{scan}^{-1}$ from m/z 30 to 350. The GC-MS data were processed using the Saturn Software package 5.2.1. Component identification was carried out using the NIST 08 mass spectral data base (NIST algorithm).

\section{Results and Discussion}

The seven major compounds alpha-thujenal, bicyclo[3.1.0]hex-3-en-2-one, 5-(1methylethyl)-, beta-thujene, 4-carene,bornyl acetate, beta-phellandrene and 1,3, 5,6-tetramethyladamantane were identified and quantified in the essential oil of L. palustre (Figure 1). The oil and the main components yields (content) were significantly affected by diurnal variation (Table 1 ). It can be seen from the table, essential oil yield varied from 1.21 to $1.62 \mathrm{~g}$ of oil per $100 \mathrm{~g}$ of dry herbage. The highest essential oil yield was obtained at 3:00 PM and 11:00 AM, and the lowest at 7:00 PM and 7:00 AM. Concentration (\%) of the main components of the $L$. palustre essential oil extract at the five harvest times has been showed in Table 2. The concentration of 4 -carene in the oil varied from $1.59 \%$ (at 7:00 $\mathrm{AM}$ ) to $1.95 \%$ (at 11:00 AM) of the total oil and was generally high from 11:00 AM to 11:00 PM. Similar to 4-carene concentration, the yield of 4-carene (a function of oil yield and 4-carene concentration in the oil) was also the highest at 11:00 AM and 3:00 PM and the lowest at 7:00 AM. The concentration and yield of bicyclo[3.1.0]hex-3-en-2-one, 5-(1-methylethyl)-(9.46\% - 12.73\% of the total oil, and 116.37 - $206.72 \mathrm{mg} / 100 \mathrm{~g}$ dry material) were the highest at 3:00 PM 
<smiles>CC1C=CC2C(C1)C2(C)C</smiles>

(+)-4-Carene

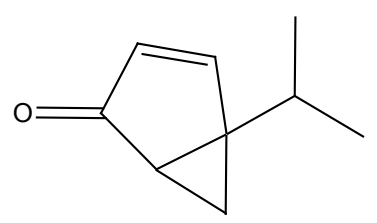

beta-Thujene

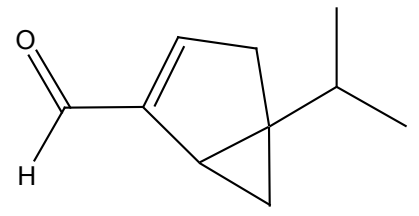

alpha-Thujenal

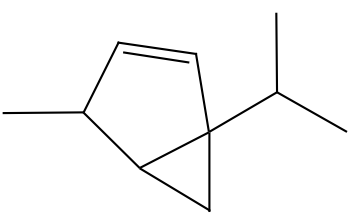

Bicyclo[3.1.0]hex-2-ene, 4-methyl-1-(1-methylethyl)-

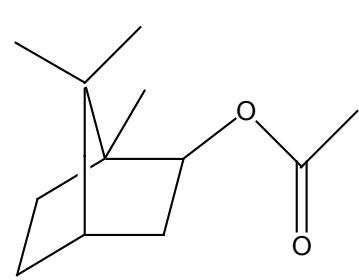

Bornyl acetate

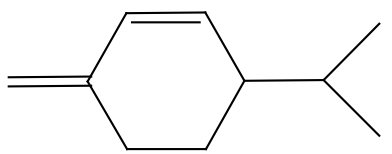

beta-Phellandrene

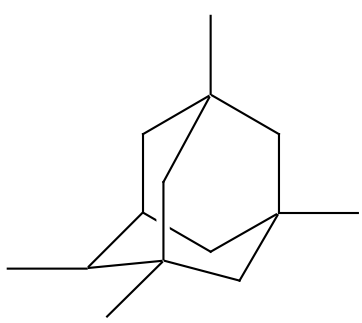

1,3,5,6-Tetramethyladamantane

Figure 1. Chemical structure of the major components of the L. palustre essential oil extract.

Table 1. Mean oil yield (oil content $\mathrm{g} / 100 \mathrm{~g}$ dry herbage) and the yield (mg/100 g dry material) of some main components at the five harvest times.

\begin{tabular}{|c|c|c|c|c|c|c|c|c|}
\hline $\begin{array}{l}\text { Harvest } \\
\text { time }\end{array}$ & Oil yield & $\begin{array}{l}\text { alpha-Thujenal } \\
\text { yield }\end{array}$ & $\begin{array}{l}\text { Bicyclo[3.1.0]hex-3-en-2-one, } \\
\text { 5-(1-methylethyl)- yield }\end{array}$ & $\begin{array}{l}\text { beta-Thujene } \\
\text { yield }\end{array}$ & $\begin{array}{l}\text { 1,3,5,6-Tetramethy }(+ \\
\text { ladamantane yield }\end{array}$ & $\begin{array}{l}\text { )-4-Caren } \\
\text { e yield }\end{array}$ & $\begin{array}{c}\text { Bornyl } \\
\text { acetate } \\
\text { yield }\end{array}$ & beta-Phellandrene \\
\hline 7:00 AM & $1.23 \mathrm{a}$ & 342.10 & 116.37 & 57.69 & 24.60 & 19.56 & 24.48 & 11.81 \\
\hline 11:00 AM & $1.56 \mathrm{c}$ & 411.60 & 188.04 & 85.57 & 36.45 & 30.51 & 35.67 & 17.36 \\
\hline 3:00 PM & $1.62 \mathrm{c}$ & 478.56 & 206.72 & 52.61 & 36.86 & 27.77 & 37.02 & 15.10 \\
\hline 7:00 PM & $1.21 \mathrm{a}$ & 343.20 & 143.15 & 28.02 & 21.59 & 20.74 & 27.42 & 11.04 \\
\hline 11:00 PM & $1.39 \mathrm{~b}$ & 308.11 & 165.04 & 32.40 & 28.78 & 23.36 & 21.55 & 12.93 \\
\hline
\end{tabular}

Within a column, means followed by the same letter are not significantly different.

and the lowest at 7:00 AM. The highest concentration and yield of beta-thujene were found at 11:00 AM and the lowest at 7:00 PM and 11:00 PM. The concentration and yield of alpha-thujenal were the highest at 3:00 PM and the lowest at 11:00 PM. The concentration of bornyl acetate was generally high from 11:00 $\mathrm{AM}$ to 7:00 PM and the lowest at 11:00 PM, whereas the yield of bornyl acetate was highest at 3:00 PM. The concentrations of beta-phellandrene and 1,3,5,6-tetramethyla-damantane range from $0.91 \%$ to $1.11 \%$, and $1.78 \%$ to $2.33 \%$, respectively. Furthermore, there is high concentration of 2 -carene $(3.97 \%-3.14 \%)$ from 11:00 AM to 11:00 PM, but no 2-carene was detected at 7:00 AM.

Predominant presence of alpha-thujene, beta-thujene and bornyl acetate in $L$. palustre essential oil was also reported in previous studies [3] [8] [22] [23] [24]. Recently, Zhao et al. [8] compared the essential oil compositions from wild $L$. palustre stems, leaves, and flowers in bloom and non-bloom periods from Northeast China. The study reported the predominant constituents in all oils were 4-thujene, 5-(1-methylethyl)-bicyclo[3.1.0]hex-3-en-2-one, alpha-thujenal 
Table 2. Concentration (\%) of the main components of the L. palustre essential oil extract at the five harvest times.

\begin{tabular}{|c|c|c|c|c|c|c|}
\hline \multirow{2}{*}{$\begin{array}{l}\text { Retention } \\
\text { time/min }\end{array}$} & \multirow{2}{*}{ Components } & \multicolumn{5}{|c|}{ Concentration (\%) } \\
\hline & & 7:00 AM & 11:00 AM & 3:00 PM & 7:00 PM & 11:00 PM \\
\hline 1.495 & Furan, tetrahydro-3-methyl- & 2.52 & 2.22 & 2.03 & 2.04 & 1.93 \\
\hline 6.9 & Bicyclo[3.1.0]hex-2-ene, 2-methyl-5-(1-methylethyl)- & 1.04 & 1.42 & 1.01 & 0.72 & 0.71 \\
\hline 7.05 & alpha-pinene & 0.46 & 0.55 & 0.41 & 0.26 & 0.23 \\
\hline 7.44 & camphene & 0.56 & 0.73 & 0.57 & 0.4 & 0.33 \\
\hline 8.17 & beta-thujene & 4.69 & 5.47 & 3.24 & 2.31 & 2.33 \\
\hline 8.25 & beta-pinene & 0.27 & 0.27 & 0.26 & 0.22 & 0.19 \\
\hline 8.59 & furan, 2-pentyl- & 0.25 & 0.29 & 0.22 & 0.2 & 0.15 \\
\hline 8.87 & alpha-phellandrene & 0.66 & 0.89 & 0.75 & 0.74 & 0.75 \\
\hline 9.22 & $(+)$-2-carene & & 3.97 & 3.36 & 3.27 & 3.14 \\
\hline 9.49 & benzene, 1,2,4,5-tetramethyl- & 5.82 & 7.25 & 7.09 & 5.84 & 5.62 \\
\hline 9.55 & beta-phellandrene & 0.96 & 1.11 & 0.93 & 0.91 & 0.93 \\
\hline 9.69 & 1,3,6-Octatriene, 3,7-dimethyl- & 0.25 & 0.33 & 0.3 & 0.24 & 0.2 \\
\hline 10.19 & 1,4-Cyclohexadiene, 1-methyl-4-(1-methylethyl)- & 4.26 & 5.16 & 4.27 & 4.21 & 4.02 \\
\hline 10.296 & beta-terpineol & 0.11 & & & & \\
\hline 10.75 & (+)-4-carene & 1.59 & 1.95 & 1.71 & 1.71 & 1.68 \\
\hline 11.55 & bicyclo[3.1.0]hex-3-en-2-one, 5-(1-methylethyl)- & 9.46 & 12.02 & 12.73 & 11.8 & 11.87 \\
\hline 11.854 & pinocarveol & 1.17 & & & & \\
\hline 12.117 & 2,6-dimethylbicyclo[3.2.1] octane & 1.37 & 1.12 & 2.12 & 1.78 & 0.9 \\
\hline 12.292 & bicyclo[3.1.0]hexan-2-one, 5-(1-methylethyl)- & 2.77 & 0.19 & 1.2 & 0.94 & 1.41 \\
\hline 12.836 & alpha-Thujenal & 27.81 & 26.31 & 29.47 & 28.29 & 22.16 \\
\hline 13.055 & $\begin{array}{c}\text { bicyclo[3.1.1]hept-2-ene-2-carboxaldehyde, } \\
\text { 6,6-dimethyl- }\end{array}$ & 1.72 & 1.68 & 1.72 & 1.68 & 6.28 \\
\hline 13.45 & Phenol, 4-(1-methylethyl)- & 1.11 & 1.18 & 1.01 & 1.09 & 0.96 \\
\hline 13.755 & Propanal, 2-methyl-3-phenyl- & & & 5.38 & 6.86 & 6.47 \\
\hline 14.33 & Bornyl acetate & 1.99 & 2.28 & 2.28 & 2.26 & 1.55 \\
\hline 14.4 & Benzenemethanol, 4-(1-methylethyl) & 1.65 & 1.9 & 1.93 & 1.97 & 1.92 \\
\hline 14.875 & o-Isopropylphenetole & 1.18 & 1.36 & 1.65 & 1.73 & 1.52 \\
\hline 14.969 & g-terpinene & 1.85 & 2.17 & 2.13 & 2.35 & 2.23 \\
\hline 16.896 & $(+)$-aromadendrene & 2.64 & 3.18 & 2.9 & 2.49 & 2.95 \\
\hline 17.5 & Shyobunone & 0.5 & 0.51 & 0.99 & 0.87 & 0.95 \\
\hline 18.747 & Ledol & & & & 0.28 & 0.27 \\
\hline 18.822 & 1,3,5,6-Tetramethyladamantane & 2 & 2.33 & 2.27 & 1.78 & 2.07 \\
\hline 19.517 & 4-Isopropyl-trans-bicyclo[4.3.0]-2-nonen-8-one & 1.49 & 1.4 & 1.37 & 1.26 & 1.59 \\
\hline Total & & 82.15 & 89.24 & 95.3 & 90.5 & 87.31 \\
\hline
\end{tabular}

and (-)-terpineol. Our study confirmed the significant difference in oil composition of L. palustre from different countries. In the previous reports, the main compositions of the essential oils from the mixture of stems and leaves of wild $L$. palustre from Da Hinggan Mountains of Northeast China were identified as alpha-thujenal (17.13\%), 5-(1-methylethyl)-bicyclo[3.1.0]hex-3-en-2-one (8.95\%), 
sabinaketone (4.96\%), 4-thujene (3.28\%) and $\gamma$-terpinene $(2.45 \%)$ [22], while sabinene (25.9\%), p-cymene (14.8\%), myrtenal (14.1\%), 4-terpineol (7.3\%) and cumin aldehyde (5.3\%) were identified as main compositions from wild L. palustre varangustum E. Busch of the same region [25]. In European varietas, ledol $(21.0 \%-32.2 \%)$ and palustrol $(26.2 \%-37.9 \%)$ were predominant constituents in Lithuania L. palustre oils [3].

Variations in terpenoid concentration in the essential oil of other species due to diurnal changes have been observed before. Variation of the terpenoid concentration has been known to be temperature dependent [26] and the concentration increases during the day, reaches maximum values at evening and decreases at night and then increases again in early morning [27]. Lopes et al. [28] reported that relative level of monoterpenes in Virola surinamensis essential oil was $28 \%$ at 6:00 AM, then dropped to approximately $15 \%$ at noon, and increased back to the same concentration at 9:00 PM. The same authors reported that, limonene, a major compound in $V$. surinamensis showed higher concentrations (19.29\% - 19.85\%) during early morning (6:00 - 9:00 AM) and dropped at 12:006:00 PM (12.59\% - 11.87\%).

Our results showed that higher essential oil yield, and alpha-thujenal and bicyclo[3.1.0]hex-3-en-2-one,5-(1-methylethyl)- yield yields, during 11:00 AM and 3:00 PM harvest times. The lowest essential oil yield was found during night and early morning harvest times. These results may be associated with diurnal variation of climatic conditions such as, light, temperature and relative humidity, and support previous reports on the effect of diurnal studies on essential oil yield of other aromatic plants. Diurnal changes in essential oil yield and composition, and hence optimal harvest time for various crops have been known for a long time. Our results are in agreement with the report by Rao et al. [17] who reported in geranium harvested during the day from 8:00 AM until 4:00 PM produced higher oil yield than that harvested at night or early morning. Similarly, Ayanoglu et al. [29] observed that essential oil content of lemon balm showed diurnal variation in two locations, oil yields were higher at noon in both locations. Bufalo et al. [10] reported the highest essential oil yield from spearmint (Mentha spicata L.) was obtained at 9:00 AM and the lowest at 7:00 PM. In experiments with Cymbopogonwinterianus, Blank et al. [30] found that oil yields were higher at noon and lower at 5:00 PM. Shevchenko [31] found the diurnal maximum and minimum essential oil accumulation in Salvia sclarea to be at noon and at 3:00 AM, respectively. However, in a diurnal study with Rosa damascena Mill., Kumar et al. [15] found the highest essential oil content at 04:00 AM and the lowest at 2:00 PM. Angelopoulou et al. [19] reported that in Cistus monspeliensis L. leaves during the months of May, August, and February, oil yield was the highest at 6:00 PM, whereas in November, the oil yield was the highest at 12:00 PM. Indeed, Lawrence [32] stated that the effect of environment factors on the accumulation of essential oil depends on plant species. Plants have different behaviors during diurnal variation. The higher temperature and solar intensity usually occurs between 11:00 AM and 2:00 PM and may be optimum 
for oil accumulation in some species [33] [34].

This study demonstrated that diurnal variation affects yield of the essential oil and composition of Chinese wild L. palustre. For best essential oil yields under northern Inner Mongolia conditions, the L. palustre acrial part should be harvested during 11:00 AM and 3:00 PM. The oil extracted from L. palustre harvested at these times contains high 4-carene,bicyclo[3.1.0]hex-3-en-2-one,5(1-methylethyl)-, beta-thujene, alpha-thujenal, bornyl acetate, and beta-phellandrene concentration. Harvests at 7:00 AM and 7:00 PM would result in low $L$. palustre oil yield, should be avoided.

\section{Acknowledgements}

This work was financially supported by National Natural Science Foundation of China (No. 31500485) and Fundamental Research Funds of CAF (CAFYBB2016QB013).

\section{References}

[1] Kim, D. and Nam, B. (2006) Extracts and Essential Oil of Ledum palustre L. Leaves and Their Antioxidant and Antimicrobial Activities. Preventive Nutrition \& Food Science, 11, 100-104. https://doi.org/10.3746/jfn.2006.11.2.100

[2] Belousova, N.I., Khan, V.A. and Berezovskaya T.P. (1990) Intraspecies Chemical Variability of the Essential Oil of Ledum palustre. Chemistry of Natural Compounds, 26, 398-405. https://doi.org/10.1007/BF00598991

[3] Butkienè, R., Šakočiūtè, V., Latvènaitè, D. and Mockutė, D. (2008) Composition of Young and Aged Shoot Essential Oils of the Wild Ledum palustre L. Chemija, 19, 19-24.

[4] Evstratova, R.I., Kabanov, V.S., Krylova, I.L. and Prokosheva, L.I. (1978) Content of Essential Oil and of Ledol in Leaves of Marsh Rosemary (Ledum palustre L.) during Different Phases of Vegetation. Pharmaceutical Chemistry Journal, 12, 1468-1473. https://doi.org/10.1007/BF00772648

[5] Mikhailova, N.S. and Rybalko, K.S. (1980) Chemical Constitution of Ledum palustre. Chemistry of Natural Compounds, 16, 131-135. https://doi.org/10.1007/BF00638770

[6] Judžentiene, A., Budiene, J., Misiunas, A. and Butkiene, R. (2012) Variation in Essential Oil Composition of Rhododendron tomentosum Gathered in Limited Population (in Eastern Lithuania). Chemija, 23, 131-135.

[7] Tejesvi, M.V., Kajula, M., Mattila, S. and Pirttilä, A.M. (2011) Bioactivity and Genetic Diversity of Endophytic Fungi in Rhododendron tomentosum Harmaja. Fungal Diversity, 47, 97-107. https://doi.org/10.1007/s13225-010-0087-4

[8] Zhao, Q., Ding, Q., Yuan, G., Xu, F., Li, B., Wang, J. and Ouyang, J. (2016) Comparison of the Essential Oil Composition of Wild Rhododendron tomentosum Stems, Leaves, and Flowers in Bloom and Non-Bloom Periods from Northeast China. Journal of Essential Oil Bearing Plants, 19, 1216-1223. https://doi.org/10.1080/0972060X.2016.1141065

[9] Dampc, A. and Luczkiewicz, M. (2013) Rhododendron tomentosum (Ledum palustre). A Review of Traditional Use Based on Current Research. Fitoterapia, 85, 130143. https://doi.org/10.1016/j.fitote.2013.01.013

[10] Bufalo, J., Zheljazkov, V.D., Cantrell, C.L., Astatkie, T., Ciampa, L. and Jeliazkova, 
E. (2015) Diurnal Effects on Spearmint Oil Yields and Composition. Scientia Horticulturae, 182, 73-76. https://doi.org/10.1016/j.scienta.2014.11.018

[11] Baghalian, K., Haghiry, A., Naghavi, M.R. and Mohammadi, A. (2008) Effect of Saline Irrigation Water on Agronomical and Phytochemical Characters of Chamomile (Matricaria recutita L.). Scientia Horticulturae, 116, 437-441.

[12] Viuda-Martos, M., Ruiz-Navajas, Y., Fernández-López, J. and Perez-Álvarez, J. (2008) Antibacterial Activity of Lemon (Citrus lemon L.), Mandarin (Citrus reticulata L.), Grapefruit (Citrus paradisi L.) and Orange (Citrussinensis L.) Essential Oils. Food Control, 19, 1130-1138.

[13] Shanjani, P.S., Mirza, M., Calagari, M. and Adams, R.P. (2010) Effects Drying and Harvest Season on the Essential Oil Composition from Foliage and Berries of Juniperus excelsa. Industrial Crops \& Products, 32, 83-87.

[14] Zheljazkov, V.D., Cantrell, C.L., Astatkie, T. and Hristov, A. (2010) Yield, Content, and Composition of Peppermint and Spearmints as a Function of Harvesting Time and Drying. Journal of Agricultural and Food Chemistry, 58, 11400-11407. https://doi.org/10.1021/jf1022077

[15] Butkiene, R. and Mockute, D. (2011) The Variability of the Essential Oil Composition of Wild L. Shoots During Vegetation Reriod. Journal of Essential Oil Research, 23, 9-13. https://doi.org/10.1080/10412905.2011.9700423

[16] Silva, M.G.D.V., Craveiro, A.A., Matos, F.J.A., Machado, M.I.L. and Alencar, J.W. (1999) Chemical Variation during Daytime of Constituents of the Essential Oil of Ocimum gratissimum Leaves. Fitoterapia, 70, 32-34.

[17] Rao, B.R., Bhattacharya, A., Kaul, P. and Ramesh, S. (2002) Yield and Chemical Composition of Rose-Scented Geranium (Pelargonium Species) Oil at Different Times of Harvesting. Journal of Essential Oil Research, 13, 456-459. https://doi.org/10.1080/10412905.2001.9699728

[18] Kumar, R., Sharma, S., Sood, S., Agnihotri, V.K. and Singh, B. (2013) Effect of Diurnal Variability and Storage Conditions on Essential Oil Content and Quality of Damask Rose (Rosa damascena Mill.) Flowers in North Western Himalayas. Scientia Horticulturae, 154, 102-108.

[19] Angelopoulou, D., Demetzos, C. and Perdetzoglou, D. (2002) Diurnal and Seasonal Variation of the Essential Oil Labdanes and Clerodanes from Cistus monspeliensis L. Leaves. Biochemical Systematics \& Ecology, 30, 189-203.

[20] Hassiotis, C.N., Lazari, D.M. and Vlachonasios, K.E. (2010) The Effects of Habitat Type and Diurnal Harvest on Essential Oil Yield and Composition of Lavandula angustifolia Mill. Fresenius Environmental Bulletin, 19, 1491-1498.

[21] Jemâa, J.M.B., Haouel, S., Bouaziz, M. and Khouja, M.L. (2012) Seasonal Variations in Chemical Composition and Fumigant Activity of Five Eucalyptus Essential Oils against Three Moth Pests of Stored Dates in Tunisia. Journal of Stored Products Research, 48, 61-67.

[22] Wang, Y. and Zhao, M. (2003) Study on the Volatile Constituents of Ledum palustre L. in the Daxingan Mountains. Chinese Journal of Chromatography, 21, 631.

[23] Zhao, D.X., Wang, H.T., Wu, C.S., Sun, S.W. and Ma, Y.P. (1987) A Preliminary Study of the Volatile Oil from Ledum palustre. Journal of Integrative Plant Biology, 2, 75-78.

[24] Chen, Q.X., Wang, X.Q., Chen, Q.H. and Wen, C.H. (2006) The Study of Extraction Methods of the Volatile Oil of Ledum palustre. Acta Academiae Medicinae Neimongol, 28, 414-416.

[25] Zhao, Z., Wang, Y., Du, X., Liu, X., Li, D. and Sun, Z. (2001) Study on the Compo- 
sition and Application of Essential Oil of Ledum palustre L. var angustum. Chemistry and Industry of Forest Products, 35, 3-5.

[26] Roberts, J.M., Hahn, C.J., Fehsenfeld, F.C., Warnock, J.M., Albritton, D.L. and Sievers, R.E. (1985) Monoterpene Hydrocarbons in the Nighttime Troposphere. Environmental Science \& Technology, 19, 364-369. https://doi.org/10.1021/es00134a011

[27] Bufler, U. and Wegmann, K. (1991) Diurnal Variation of Monoterpene Concentrations in Open-Top Chambers and in the Welzheim Forest Air, F.R.G. Atmospheric Environment Part A General Topics, 25, 251-256.

[28] Lopes, N.P., Kato, M.J., de Aguiar-Andrade, E.H., Soares-Maia, J.G. and Yoshida, M. (1997) Circadian and Seasonal Variation in the Essential Oil from Virola surinamensis Leaves. Phytochemistry, 46, 689-693.

[29] Ayanoglu, F., Arslan, M. and Hatay, A. (2005) Effects of Harvesting Stages, Harvesting Hours and Drying Methods on Essential Oil Content of Lemon Balm Grown in Eastern Mediterranean. International Journal of Botany, 1, 138-142. https://doi.org/10.3923/ijb.2005.138.142

[30] Blank, A.F., Costa, A.G., Arrigoni-Blank, M.D.F., Cavalcanti, S.C.H., Alves, P.B., Innecco, R., Ehlert, P.A.D. and Sousa, I.F.D. (2007) Influence of Season, Harvest Time and Drying on Java citronella (Cymbopogon winterianus Jowitt) Volatile Oil. Revista Brasileira de Farmacognosia, 17, 557-564. https://doi.org/10.1590/S0102-695X2007000400014

[31] Shevchenko, S. (1973) Seasonal and Diurnal Changes in Salvia sclarea Essential Oil Content. Rastitel nye Resursy, 9, 566-570.

[32] Lawrence, B.M. (1988) A Further Examination of the Variation of Ocimum basilicum L. Developments in Food Science, 18, 161-170.

[33] Ramezani, S., Ramezani, F., Rasouli, F., Ghasemi, M. and Fotokian, M.H. (2009) Diurnal Variation of the Essential Oil of Four Medicinal Plants Species in Central Region of Iran. Research Journal of Biological Sciences, 4, 103-106.

[34] Ramezani, S., Rahmanian, M., Jahanbin, R., Mohajeri, F., Rezaei, M.R. and Solaimani, B. (2012) Diurnal Changes in Essential Oil Content of Coriander (Coriandrum sativum L.) Aerial Parts from Iran. Research Journal of Biological Sciences, 4 , 277-281.

\section{Submit or recommend next manuscript to SCIRP and we will provide best service for you:}

Accepting pre-submission inquiries through Email, Facebook, LinkedIn, Twitter, etc. A wide selection of journals (inclusive of 9 subjects, more than 200 journals) Providing 24-hour high-quality service User-friendly online submission system Fair and swift peer-review system Efficient typesetting and proofreading procedure Display of the result of downloads and visits, as well as the number of cited articles Maximum dissemination of your research work

Submit your manuscript at: http://papersubmission.scirp.org/

Or contact jasmi@scirp.org 